\title{
Effects of Land Use on the Amount and Composition of Dissolved Organic Matter in a Chinese Headwater Stream Watershed
}

\author{
Bingbing Xu, Qinghui Huang, Jianhua Li*, Penghui Li, \\ Yuanjing Xiang, Junichi Takahashi \\ Key laboratory of Yangtze River Water Environment of the Ministry of Education, \\ College of Environmental Science and Engineering, Tongji University, \\ Shanghai 200092, China
}

Received: 25 January 2015

Accepted: 22 October 2015

\begin{abstract}
The source and composition of dissolved organic matter (DOM) are important drivers of its biogeochemical role in aquatic environments. Different land use types may alter DOM amount and composition in freshwaters. Here, water samples were collected from the outlets of 16 subcatchments within mixed land use patterns in the South Tiaoxi River in Eastern China. Dissolved organic carbon (DOC), DOM absorption coefficient $\left(\alpha_{350}\right)$, and fluorescence spectrum were measured. These 16 subcatchments were grouped into four clusters with different land use features: natural forest land, planted forest land (Phyllostachys praecox, a bamboo species), cropland, and residential land. Two humic-like and two protein-like fluorescent components were identified using parallel factor analysis (PARAFAC). DOC concentrations were the lowest in natural forest land dominated subcatchments as compared to other land uses with intensive anthropogenic activities, so did $\alpha_{350}$ and fluorescent intensities of different components. Protein-like fluorescence was more pronounced for the subcatchments dominated by residential land, while terrestrial humic-like fluorescence was the most abundant component for the subcatchments dominated by the other three land use types. The relationships between the percentage of cropland and that of fluorescence fraction appear to be a threshold response, indicating that effects on DOM composition varied with agricultural activity patterns. The reservoir would have a positive effect on DOM amount and the percentage of protein-like fluorescence associated with autochthonous activities. This study in general shows the impact of anthropogenic land use patterns on the amount and composition of DOM in headwater streams, which may affect ecosystem function and health of aquatic environments.
\end{abstract}

Keywords: dissolved organic matter, fluorescence, land use, PARAFAC, South Tiaoxi River

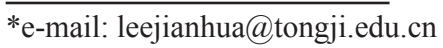




\section{Introduction}

Dissolved organic matter (DOM) is a complex mixture of aromatic and aliphatic organic constituents derived from both natural and anthropogenic sources in aquatic environments. It plays important biogeochemical roles and has major implications for ecosystem functioning in streams. DOM regulates the light environment, which may influence aquatic primary producers for available light. Heterotrophic bacteria can also utilize DOM as the primary source of carbon and energy [1]. DOM can also affect aquatic ecosystems by transporting nutrients, heavy metals, and other pollutants. Thus, understanding the dynamics of DOM in an aquatic environment is of considerable significance.

Roles of DOM in biogeochemical processes are controlled by its structure, composition, and relative abundance [2]. The quality and quantity of riverine DOM are affected by its physicochemical properties and a number of factors related to watershed characteristics, such as geomorphology, hydrologic regimes, land use, and microbial activity [3-5]. Among them, land use has been considered one of the crucial factors that can influence DOM characteristics in streams by altering terrestrial loading and autochthonous production. To detect any DOM changes that are driven by land use, it is advantageous to investigate DOM inputs into headwater streams, which are the first surface water systems in the land to ocean continuum [6]. However, only a few studies have been done to show the variations in DOM characteristics as a result of changes in land use types at catchment level in headwaters.

Excitation-emission matrix fluorescence spectroscopy and parallel factor analysis (EEMs-PARAFAC) techniques are widely utilized for identifying the source and composition of DOM in aquatic environments [2, 7]. Previous studies have reported that the components revealed by PARAFAC were closely related to different types of land use, such as agricultural land, wetland, and residential area $[4,5,8]$. In southeast China, Yang [8] observed significant positive relationships between the percentage of protein-like fluorescence and that of residential area in a subtropical river watershed, suggesting anthropogenic influences on DOM. However, changes in DOM composition with other land use types (e.g., planted forest land) remain to be elucidated in the headwater streams.

The South Tiaoxi River in eastern China is a typical piedmont headwater stream. It is upstream of the East Tiaoxi River, which is the largest inflow river of Taihu Lake. It is composed of subcatchments with mixed land use patterns. In recent years, anthropogenic activities have had a profound impact on changing land use of the South Tiaoxi River, including urbanization [9], agricultural activities [10], and planted forests of Phyllostachys praecox [11]. P. praecox is one of the best bamboo species for edible bamboo shoot production and major planted forests in this watershed. In contrast to natural forest land, $P$. praecox is intensively managed by heavy fertilization and organic mulch used to promote the early production of bamboo shoots with high yields [12]. Previous studies demonstrated that those measures increased water-soluble soil organic-carbon (WSOC) and -nitrogen (WSON) concentrations [11, 13]. However, our understating of the potential impact of those agricultural activities on DOM composition is quite limited. Moreover, the spatiotemporal variations of DOM components and their associations to land use types in the South Tiaoxi have not been extensively investigated.

The objectives in the present paper are: 1) to characterize spatial and temporal variations in the amount of DOM, 2) to identify the fluorescent components and its variations in space and time, and 3) to clarify the relationships between DOM components and land use patterns.

\section{Materials and Methods}

\section{Study Area}

The South Tiaoxi River is a typical mountain stream originating in Tianmu Piedmont in eastern China. It drains an area of $629 \mathrm{~km}^{2}$ and consists of three major tributaries, namely Langkouxi, Nanxi, and Jinxi streams (Fig. 1). Nanxi is the main tributary and converges with Langkouxi at Qiaodong village, then downstream of the confluence site is the South Tiaoxi. Both the South Tiaoxi and Jinxi flow through Lin'an, the biggest town and major population center of the watershed, and enter into Qingshanhu Reservoir at Changqiao Bridge (S2) and Sanyanqiao Bridge (J6), respectively. There is another reservoir named Lifan that supplies drinking water for residents in Lin'an.

Stream gradient is $1 / 100$ and decreases as these rivers flow into the relatively flat region in the lower reaches. The climate is humid subtropical and the average annual temperature is $15.8^{\circ} \mathrm{C}$ (based on 2013 data). The annual average precipitation is $1,500 \mathrm{~mm}$, unevenly distributed throughout the year. Affected by Asian monsoon, 75\% of the precipitation is concentrated from April to September. The plum rain season occurs from mid-May to mid-July, while the typhoon season occurs after plum rain season and lasts into mid-October. Soil types are mainly paddy soil and mountain soil (e.g., alluvial soil, yellow loam, and red loam). Forestry is the main land use throughout the watershed, including natural and planted forest land, and fewer cropland and residential areas are distributed. Planted forest land is widely distributed in Nanxi Stream, while intensive agriculture distributes abroad in upstream Jinxi Stream. Local residents settle along the whole river in the catchment.

\section{Landscape Characterization}

Previous studies have classified land use of the studied or adjacent watershed into different categories. Four land use categories - natural forest land, cropland, residential area, and water body - were separated using a 1:250,000 
digital land use map of Zhejiang Province in Data-Sharing Network of Earth System Science (http://www.geodata.cn). Six land use categories - natural forest land, water body, residential area, grassland, cropland, and bare land - were separated in the West Tiaoxi River [14]. Here, in order to improve classification accuracy and distinguish planted forest land from forestry, 18 topographic maps $(1: 10,000)$ were digitized by a manual on-screen method. The watershed was divided into 16 subcatchments by ArcGIS 9.3 hydrology analysis software. Land use area of each subcatchment was calculated. The proportion of grassland and bare land was negligible in those subcatchments. Therefore, the studied watershed was classified into five land use categories: natural forest, planted forest, cropland, residential land, and water body.

\section{Field Sampling}

Sixteen surface water samples were collected from subcatchment outlets, including four locations in Langkouxi stream (L1-L4), four locations in Nanxi stream (N1-N4), six locations in Jinxi stream (J1-J6), and two locations in the South Tiaoxi River (S1-S2) (Fig. 1). Seven water sampling campaigns were divided into three hydrologic seasons according to precipitation, namely wet season (June and October), normal season (April, May and December), and dry season (July and September) (Fig. 2). The average monthly rainfall in this watershed was typically around $123 \mathrm{~mm}$. The average rainfall of the wet season was $268 \%$ higher than the average monthly rainfall, while the average rainfall of the dry season made up approximately a quarter of the average monthly

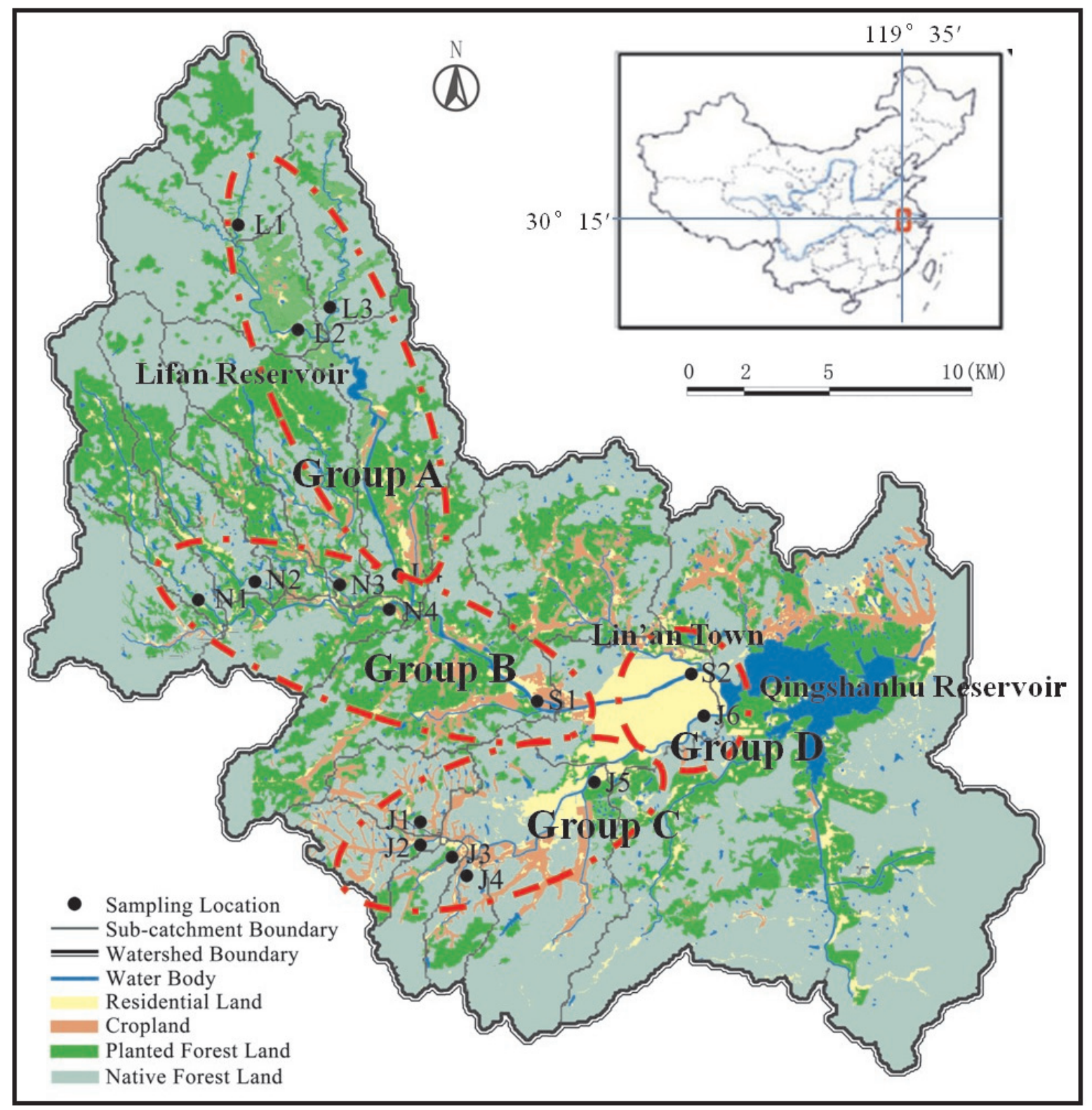

Fig. 1. Site map showing sampling locations, subcatchment boundaries, land use types, and cluster results for the South Tiaoxi River Basin. 


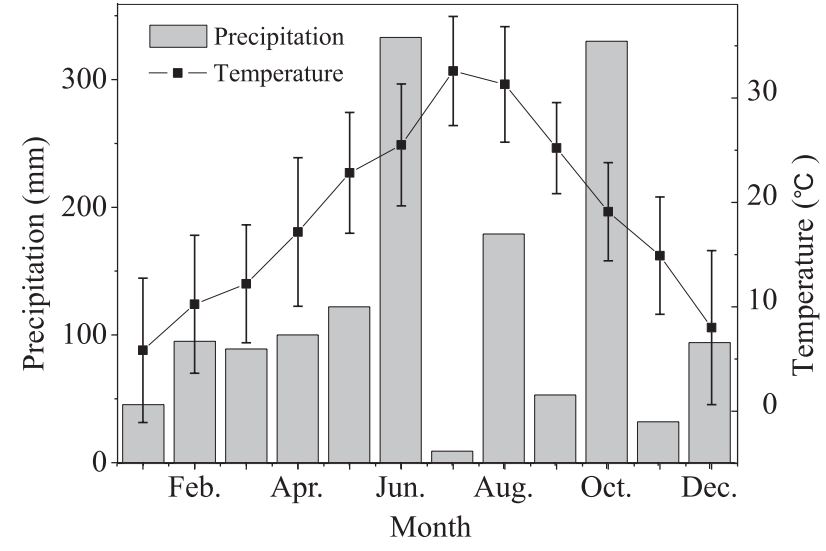

Fig. 2. Monthly variations of rainfall and temperature for the South Tiaoxi River Basin during the research period.

rainfall. Water samples in $1 \mathrm{~L}$ acid-cleaned plastic bottles were stored with an ice bag in the field. When water samples were transported to the laboratory, they were filtered through cellulose acetate membranes (pore sizes of $0.45 \mu \mathrm{m})$ as soon as possible. Filtrates were stored in the cold $\left(4^{\circ} \mathrm{C}\right)$ and in the dark prior to analysis.

\section{DOC and Absorption Measurements}

DOC was measured as non-purgeable organic carbon using a total organic carbon analyzer (TOC-VCPN, Shimadzu, Japan) with high-temperature combustion technique after acidifying water samples ( $\mathrm{pH}$ 2-3). Absorption spectra were scanned using a double-beam spectrophotometer (TU-1901, Peking Purkinje General, China) at wavelengths of 200-800 nm (1-nm intervals). Milli-Q water was used in a reference cell. Absorbance measurements $\left(\mathrm{A}_{\lambda}\right)$ were baseline corrected by subtracting the mean absorbance from 680 to $700 \mathrm{~nm}$, and then converted to absorption coefficient $\left(\alpha_{\lambda}\right)$ using the following equation:

$$
\alpha_{\lambda}=2.303 \times \mathrm{A}_{\lambda} / \mathrm{r}
$$

...where $\alpha_{\lambda}$ is the absorption coefficient at wavelength (unit, $\mathrm{m}^{-1}$ ), $\mathrm{A}_{\lambda}$ is the corrected absorbance value, and $\mathrm{r}$ is the cuvette path length (unit, $\mathrm{m}$ ). $\alpha_{350}$ is expressed as an indicator of DOM concentration.

\section{Fluorescence Measurements and PARAFAC}

Excitation-emission matrices (EEMs) fluorescence spectra were measured using an AquaLog fluorescence spectrophotometer (HORIBA Jobin Yvon, France). The emission wavelengths were scanned from 250 to $550 \mathrm{~nm}$ at $2 \mathrm{~nm}$ intervals, with the excitation wavelengths from 240 to $400 \mathrm{~nm}$ at $3 \mathrm{~nm}$ steps. Milli-Q water was used as blank. The inner-filter effect was eliminated following the tutorial by McKnight et al. [15]. Raman peaks of the Milli-Q water computed by the emission wavelengths of $380-420 \mathrm{~nm}$ at $350 \mathrm{~nm}$ excitation wavelength were used to normalize the fluorescence signals to make them comparable in different batches of the measurement [16]. Different fluorescent components were identified by Parallel factor analysis (PARAFAC), which was performed on 112 EEMs of water samples using MATLAB (Ver. 7.7.0, 2008b, the Math Works Inc., USA) with the DOMFluor toolbox [17]. The number of components was determined by split-half validation. The fluorescence intensity of each component was represented by the maximum fluorescence ( $F_{\max }$, R.U.) [3]. The relative contribution of each component was calculated as the ratio of each component to $F_{\text {max }}$ sum of all components [8].

\section{Statistical Analyses}

Hierarchical cluster analysis was applied to group sampling locations on the basis of the percentage of land use. The data were processed by Ward's method of linkage with squared Euclidean distance as a measure of similarity [18]. Significant differences of $\alpha_{350}$ and DOC among locations or seasons were determined using Tukey's parametric test [19]. To examine the relationships between the relative contribution of each component and the percentage of land use, regression analysis was determined at the $p$-value of 0.05 . Prior to the data analyses, the percentage of land use and the relative contribution of each component were arc-sin square root transformed to meet conditions of normality [20]. All statistical analyses were performed with the Statistical Program for Social Sciences (SPSS) 16.0 software.
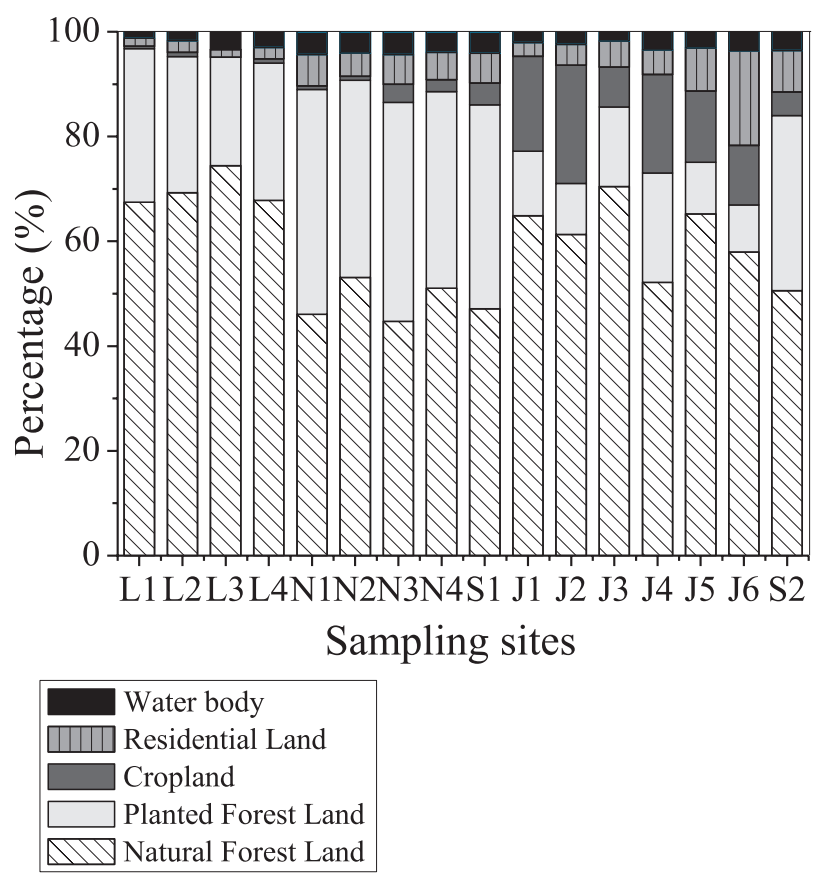

Fig. 3. Percentages of five land use categories for 16 subcatchments in the South Tiaoxi River Basin. 
Table 1. Spatial and seasonal variations of $\alpha 350$ and DOC in the South Tiaoxi River watershed.

\begin{tabular}{|c|c|c|c|c|c|}
\hline & Season & Group A & Group B & Group C & Group D \\
\hline \multirow{3}{*}{$\alpha_{350}\left(\mathrm{~m}^{-1}\right)$} & Wet & $1.05 \pm 0.19^{\mathrm{Ab}}$ & $2.21 \pm 0.67^{\mathrm{Aa}}$ & $2.12 \pm 1.05^{\mathrm{Aa}}$ & $2.55 \pm 0.53^{\mathrm{Aa}}$ \\
\cline { 2 - 6 } & Normal & $0.69 \pm 0.13^{\mathrm{Bc}}$ & $1.45 \pm 0.28^{\mathrm{ABb}}$ & $1.52 \pm 0.58^{\mathrm{Ab}}$ & $2.80 \pm 0.71^{\mathrm{Aa}}$ \\
\cline { 2 - 6 } & Dry & $0.51 \pm 0.41^{\mathrm{Ba}}$ & $1.12 \pm 1.03^{\mathrm{Ba}}$ & $1.21 \pm 1.14^{\mathrm{Aa}}$ & $2.01 \pm 1.02^{\mathrm{Aa}}$ \\
\hline \multirow{3}{*}{$\mathrm{DOC}(\mathrm{mg} / \mathrm{L})$} & Wet & $1.32 \pm 0.61^{\mathrm{Bb}}$ & $4.01 \pm 3.38^{\mathrm{Aa}}$ & $1.94 \pm 0.87^{\mathrm{Bab}}$ & $3.93 \pm 1.31^{\mathrm{Aa}}$ \\
\cline { 2 - 6 } & Normal & $2.05 \pm 0.41^{\mathrm{ABa}}$ & $2.82 \pm 0.83^{\mathrm{Aa}}$ & $3.28 \pm 1.44^{\mathrm{Aa}}$ & $2.87 \pm 1.24^{\mathrm{Aa}}$ \\
\cline { 2 - 6 } & Dry & $2.60 \pm 0.41^{\mathrm{Ab}}$ & $2.88 \pm 0.80^{\mathrm{Ab}}$ & $2.45 \pm 0.58^{\mathrm{ABb}}$ & $4.31 \pm 0.74^{\mathrm{Aa}}$ \\
\hline
\end{tabular}

Note: Data are represented as the Mean \pm S.D., the same superscript letter is not statistically different (Tukey test, $p=0.05$ ). Tukey test was processed spatially (cluster results of land use) and temporally (hydrologic seasons), respectively. Capital letters indicate significant differences between different seasons under the same land use groups, while lowercase letters represent significant differences between different land use groups under the same hydrological seasons.

\section{Results and Discussion}

\section{Cluster Analysis Results}

The relative distributions of five land use categories for 16 subcatchments are presented in Fig. 3. Land use was primarily dominated by natural forest land (45-74\%), followed by planted forest land (9-43\%). Cropland ranged from 0 to $23 \%$, while residential land ranged from 1 to $18 \%$. The 16 subcatchments were grouped into three clusters on the basis of the percentage of land use (Fig. 1). Group A included all four subcatchments along Langkouxi Stream and was characterized by the highest proportion of natural forest $(67-74 \%)$, a steep slope (29-30 $)$, and high elevation $(622-813 \mathrm{~m})$. Although the proportion of planted forest was $21-29 \%$, planted forest was not intensively managed and the characteristics of a planted forest were similar to those of a natural forest. The proportion of agricultural land, residential land, and water body was minor $(<5 \%)$. Group B included four subcatchments along the Nanxi and two subcatchments along the South Tiaoxi, and was characterized by a relatively high proportion of planted forest $(37-43 \%)$, which was intensively managed. Group $\mathrm{C}$ included six subcatchments along the Jinxi and was characterized by a relatively high proportion of cropland $(8-23 \%)$. Although these subcatchments were dominated by natural forest $(52-70 \%)$, agriculture was intensively managed and distributed along the river riparian zone. Thus agriculture had directly changed the amounts and compositions of DOM in these subcatchments. After taking into account the influence of the town of Lin'an, S2 and J6 were removed from Group B and Group C, respectively, and then merged into a new group (Group D) (Fig. 1). Group D located in the river mouth of the city area and was characterized by a relatively high proportion of residential land in these two subcatchments, at $8 \%$ and $18 \%$.

\section{Spatial and Seasonal Distribution of $\alpha 350$ and DOC}

$\alpha_{350}$ and DOC showed significant differences among four groups of land use or hydrologic seasons (Table 1,
Tukey test, $p<0.05$ ). $\alpha_{350}$ ranged from 0.11 to $7.26 \mathrm{~m}^{-1}$, with a mean of $1.61 \mathrm{~m}^{-1}$. DOC concentration varied from 0.61 to $14.70 \mathrm{mg} / \mathrm{L}$ and $90 \%$ of samples were within the range of $0.61-4.73 \mathrm{mg} / \mathrm{L}$. DOC had a similar spatial trend to $\alpha_{350} . \alpha_{350}$ and DOC of subcatchments dominated by natural forest land were significantly lower than other land uses with intensive anthropogenic activities. Thus, anthropogenic activities presumed to affect the amounts of DOM. Previous studies had shown that increases of river DOM concentrations resulted from the change of land use from forest and wetland to urban [2,21].

As a result of the lack of effective water protection measures, municipal and industrial organic matter input to surface waters had still increased in rural areas of China. Although the proportion of residential land in the catchment was reasonably low (on average 5\%), local residents settle along the whole river combined with rough domestic wastewater treatment resulted in higher organic matter [22]. Furthermore, greater elevation and steeper slope had a high extent of natural forest land, which was unfavorable for accumulating organic matter.

$\alpha_{350}$ was significantly higher in the wet season than in the normal and dry seasons, which increased with an increase of hydrologic gradient regardless of land use. Therefore, it was suggested that increased precipitation or runoff would result in increased DOM exports [2]. However, the DOC concentration did not vary with seasons. A recent study indicated that increased runoff did not have a significant effect on DOC concentrations in headwater stream [23].

\section{Fluorescence Characteristics of DOM}

Two protein-like components ( $\mathrm{C} 1$ and $\mathrm{C} 2)$ and two humic-like components ( $\mathrm{C} 3$ and $\mathrm{C} 4$ ) were identified by PARAFAC of 112 DOM samples. Fig. 4 shows the EEMs spectra of the four components. The characteristics of EEMs spectra were similar to those in other reported aquatic environments [2,24]. C1 was characterized by peak at $273 \mathrm{~nm}$ excitation with $320 \mathrm{~nm}$ emission wavelengths (Fig. 4a), which was confirmed as an autochthonous tyrosine-like fluorescence peak $\mathrm{T}$ in the EEMs plots [25]. C2 was composed of two excitation maxima at $<240 \mathrm{~nm}$ and $282 \mathrm{~nm}$, with one emission peak centered 

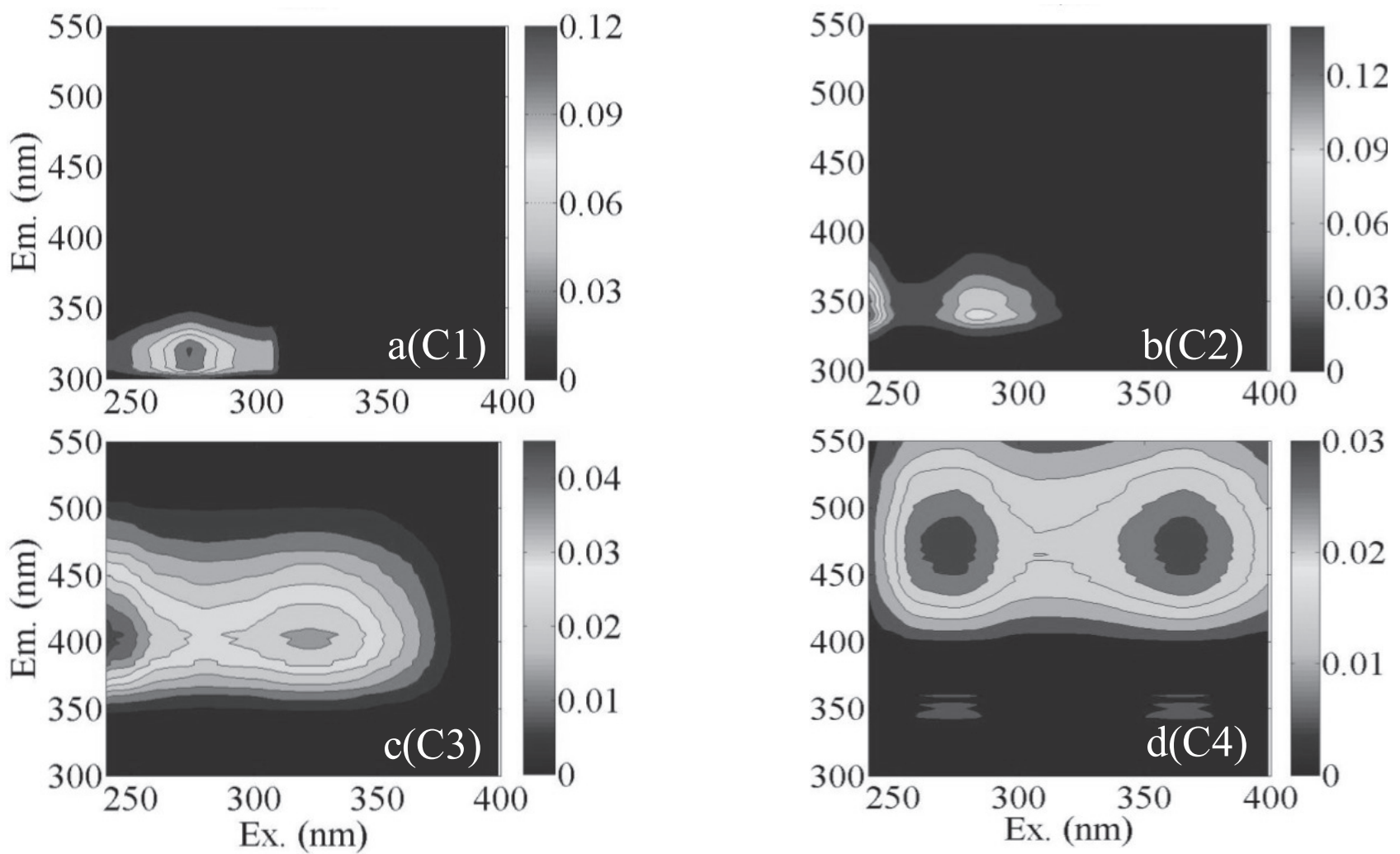

Fig. 4. Excitation-emission matrix spectra contour of the four fluorescent components identified by PARAFAC.

at $340 \mathrm{~nm}$, which was an autochthonous tryptophanlike fluorescence (Fig. 4b). C3 exhibited primary and secondary excitation fluorescence peaks at $<240 \mathrm{~nm}$ and $321 \mathrm{~nm}$, with an emission maximum at $402 \mathrm{~nm}$ (Fig. 4c), which could be categorized as the previously defined terrestrial humic-like peak A and the marine humic-like fluorescence peak M. Previous studies had demonstrated that this component may be either terrestrially derived or produced autochthonously in aqueous environments from terrestrial organic substrates $[2,26]$. C4 also exhibited a primary and secondary excitation fluorescence peak at $275 \mathrm{~nm}$ and $365 \mathrm{~nm}$ with an emission maximum at 471 $\mathrm{nm}$. It was suggested to represent humic material exported from terrestrial sources, because of the similarity with the traditional terrestrial humic-like fluorescence peak $\mathrm{C}$ (Fig. 4d). As fluorescence peaks of C4 were red-shifted compared to $\mathrm{C} 3, \mathrm{C} 4$ indicated a higher degree of aromatic polycondensation and greater chemical stability.

The mean values of the four PARAFAC components expressed by the maximum fluorescence intensities $\left(F_{\max }\right)$, were compared for all the sampling regions at the three different sampling periods in Fig. 5. The spatial distribution of all types of $F_{\text {max }}$ for the three hydrologic seasons showed similar trends as $\alpha_{350}$ along the land use types. It was suggested that the spatial variations of the DOM components were controlled by the same factors as $\alpha_{350}$ [2]. Overall, the percentage of humic-like components on an average of $54 \%$ was slightly higher than that of proteinlike components on an average of $46 \%$. The percentage of humic-like materials was highest in watershed dominated by natural forest land on an average of $64 \%$. Previous studies found that DOM in the soils and the stream was dominated by humic-like components in the forest watersheds $[8,27]$. By comparison, the highest abundance of protein-like components was observed in watersheds dominated by residential land. It was presumed that protein-like might be closely related to the anthropogenic organic pollution. Lin'an was the primary contributor of living sewage and wastewater, which were rich in the protein-like component. The $F_{\max }$ of C3 was the highest among components in upstream watersheds. It implied a close association between $\mathrm{C} 3$ and terrestrial DOM sources. In addition, the $F_{\text {max }}$ of $\mathrm{C} 3$ and $\mathrm{C} 4$ also exhibited greater values in the residential area than in the upstream sampling sites. Thus, the anthropogenic activities could also lead to the input of terrestrial humic-like substances [28]. As there were no significant seasonal differences in $F_{\max }$, the hydrological processes presumed not to affect the distribution of DOM components. The seasonal variability of DOM likely resulted from a number of factors such as rainfall, photodegradation, and microbial uptake [28]. Photodegradation and microbial uptake of DOM could be elevated during the summer, which might change the composition of DOM.

\section{The Correlations between DOM Composition and land use}

Table 2. shows the relationships of arc-sin square root transformed percentage of components against 

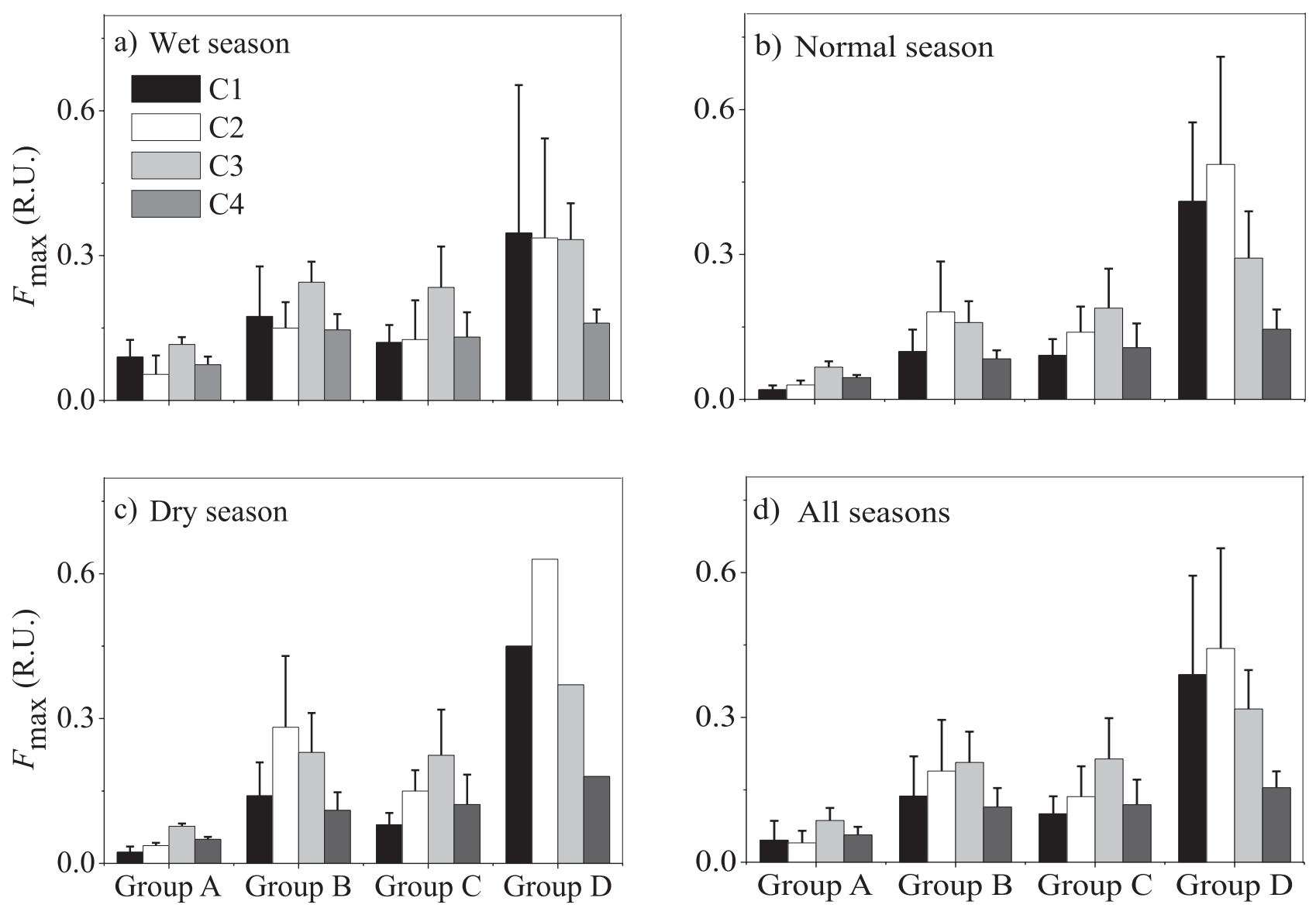

Fig. 5. Spatial and seasonal variations of maximum fluorescence intensities $\left(F_{\max }\right)$ of the four components in the different land use groups for the South Tiaoxi River Basin. The error bar represents standard deviation.

each other (C1-C4\%). $\mathrm{C} 3 \%$ and $\mathrm{C} 4 \%$ was positively correlated $(r=0.83, p<0.001)$, followed by $\mathrm{C} 1 \%$ and $\mathrm{C} 2 \%$ $(r=0.76, p=0.001)$, indicating that these components had a common factor controlling their concentrations [7]. The relationships between $\mathrm{C} 1 \%$ and $\mathrm{C} 3 \%$, and $\mathrm{C} 1 \%$ and C4\% were negatively correlated $(r=-0.87, p<0.001)$, so did $\mathrm{C} 2 \%$ and $\mathrm{C} 3 \%, \mathrm{C} 2 \%$ and $\mathrm{C} 4 \%(r=-0.76, p=0.001$; $r=-0.96, p<0.001)$. These results were used to interpret the relationships between DOM components and land use types.

DOM components appeared to have a threshold response to the proportion of cropland (Fig. 6a-b). The arc-sin square root transformed a fraction of protein-like $\mathrm{C} 1 \%$ and $\mathrm{C} 2 \%$, which decreased when the proportion of cropland exceeded $10 \%$. With regard to catchment characteristics, fertilization patterns could have been a possible cause for this. In the subcatchments of Langkouxi and Nanxi streams the proportion of cropland was less than $10 \%$. Vegetable distributions were scattered along the river and organic fertilizer (i.e., manure) was used. In the upstream region of Jinxi stream, the proportion of cropland was more than $10 \%$, in which paddy rice was the main crop and inorganic fertilizer was used. A previous study has shown that DOM derived from organic fertilizers have higher percentages of fluorophores similar to tryptophan and tyrosine in the agricultural catchments [29]. Moreover, it has been reported that terrestrial humiclike fluorescence was a predominant contributor among PARAFAC components in agricultural catchments [6]. The DOM composition of agricultural watershed has been affected by changes in a variety of environmental factors including tillage, land use history, soil types, and so on.

Table 2. Correlations between percentages of four arc-sin square root transformed components.

\begin{tabular}{|c|c|c|c|}
\hline & $\arcsin \sqrt{(\mathrm{C} 1 \%)}$ & $\arcsin \sqrt{(\mathrm{C} 2 \%)}$ & \\
\hline $\arcsin \sqrt{(\mathrm{C} 2 \%)}$ & $0.76^{* *}$ & & \\
\hline $\arcsin \sqrt{(\mathrm{C} 3 \%)}$ & $-0.87^{* *}$ & $-0.76^{* *}$ & $0.83^{* *}$ \\
\hline $\arcsin \sqrt{(\mathrm{C} 4 \%)}$ & $-0.87^{* *}$ & $-0.96^{* *}$ & \\
\hline
\end{tabular}

$* \mathrm{p}<0.05, * * \mathrm{p}<0.01$ 
The arc-sin square root transformed fraction of proteinlike $\mathrm{C} 1$ and $\mathrm{C} 2$ to that of residential land were positively correlated. In contrast, the arc-sin square root transformed fractions of humic-like $\mathrm{C} 3$ and $\mathrm{C} 4$ to correlate negatively with that of residential land (Figs 6c-d). The result was consistent with observations in other Chinese subtropical river watersheds [8]. It might be related to sewage discharge and algal growth simulated by anthropogenic nutrient inputs, which are sources for protein-like DOM.

The effects of Lifan Reservoir on DOM characteristics were shown in Table 3. The reservoir had a positive effect on DOC concentrations and $\alpha_{350}$. Thus, it was suggested that the reservoir received additional DOM from aquatic products. The proportion of autochthonous tryptophanlike and tyrosine-like fluorescence increased flow through the reservoir. It was suggested that DOM in the reservoir region was primarily produced by recent autochthonous activities [30]. Then the recently produced DOM may be further used by microbial and degraded to humic-like materials, which accounted for enhancement of humic-like fluorescence intensity, despite the fact that the percentage of humic-like fluorescence decreased [31].
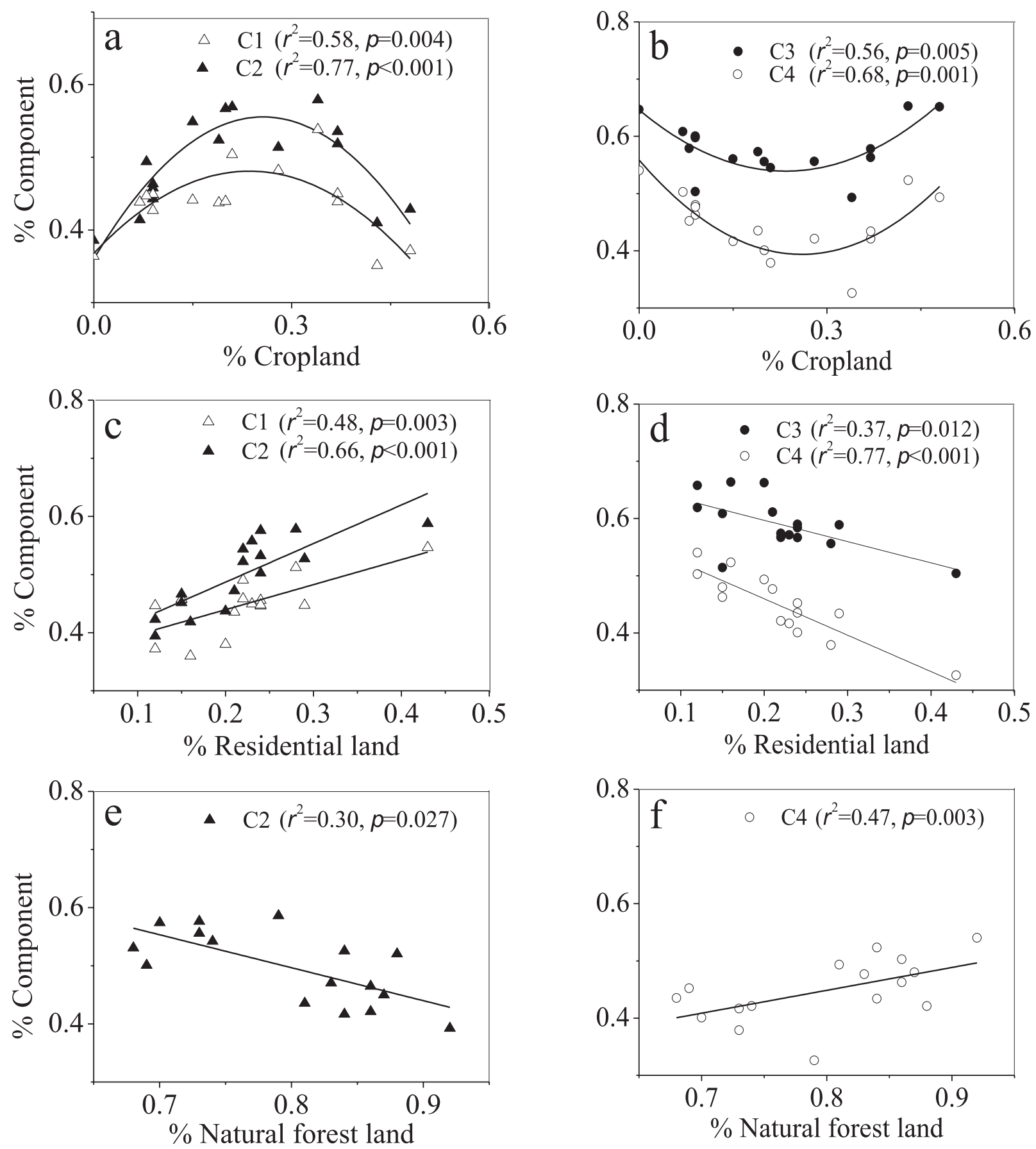

Fig. 6. Linear and non-linear regressions between fluorescence components and land use types. All variables were arc-sin square-root transformed. 
Table 3. Effect of Lifan Reservoir on the amount and composition of DOM.

\begin{tabular}{|c|c|c|c|c|c|c|c|c|c|c|}
\hline \multirow{2}{*}{ Sites } & $\alpha_{350}$ & DOC & $\mathrm{C} 1 \%$ & $\mathrm{C} 2 \%$ & $\mathrm{C} 3 \%$ & $\mathrm{C} 4 \%$ & $\mathrm{C} 1$ & $\mathrm{C} 2$ & $\mathrm{C} 3$ & $\mathrm{C} 4$ \\
\hline & $\mathrm{m}^{-1}$ & $\mathrm{mg} / \mathrm{L}$ & \multicolumn{4}{|c|}{$\%$} & \multicolumn{4}{|c|}{ R.U. } \\
\hline Inflow & 0.65 & 1.85 & 14.29 & 14.29 & 42.86 & 28.57 & 0.03 & 0.03 & 0.09 & 0.06 \\
\hline Outflow & 0.93 & 2.04 & 35.62 & 31.51 & 23.29 & 9.59 & 0.26 & 0.23 & 0.17 & 0.07 \\
\hline
\end{tabular}

Note: The fluorescent intensities are expressed in Raman units (R.U.).

\section{Conclusions}

The amount and composition of DOM in the South Tiaoxi River watershed were more likely to be driven by land use patterns rather than hydrologic regime. DOC concentrations and $\alpha_{350}$ values were lower in subcatchments dominated by natural forest land than those dominated by cropland, planted forest land, and residential land. Thus, anthropogenic activities might have increased the amount of DOM. Four components comprising two humic-like components and two protein-like components were identified using the EEMs-PARAFAC model. Protein-like components were the most dominant components in subcatchments within residential land, but terrestrial humic-like components were more abundant in subcatchments within other land use types (natural forest land, planted forest land, and cropland). Thus, anthropogenic activities also were presumed to influence DOM composition. Meanwhile, land use played important roles in shaping the DOM composition. The percentage of protein-like components increased when flowing through Lifan Reservoir. The observation supported the view that protein-like components arose from autochthonous production in freshwater. In addition, the alterations in DOM composition were presumed to be related to agricultural management practices. The present results suggested that land use patterns as an important driver of DOM amount and composition alterations in headstreams. These alterations may affect biogeochemical processes in aquatic ecosystems.

\section{Acknowledgements}

This research was financially supported by the National Natural Science Foundation of China (Grant Nos. 41071301 and 40601095), the Science and Technolo-gy Commission of Shanghai Municipality (Nos. 13DJ1400103, 13DJ1400104, and 13231203703), and the Fundamental Research Funds for the Central Universities (0400219216).

\section{References}

1. JAFFE R., BOYER J.N., LU X., MAIE N., YANG C., SCULLY N.M., MOCK S. Source characterization of dissolved organic matter in a subtropical mangrovedominated estuary by fluorescence analysis. Mar Chem. 84, (3-4), 195, 2004.
2. ZHANG Y.L., YIN Y., FENG L.Q., ZHU G.W., SHI Z.Q., LIU X.H., ZHANG Y.Z. Characterizing chromophoric dissolved organic matter in Lake Tianmuhu and its catchment basin using excitation-emission matrix fluorescence and parallel factor analysis. Water Res. 45 (16), 5110, 2011.

3. HONG H.S., YANG L.Y., GUO W.D., WANG F.L., YU X.X. Characterization of dissolved organic matter under contrasting hydrologic regimes in a subtropical watershed using PARAFAC model. Biogeochemistry. 109 (1-3), 163, 2012.

4. HUR J., NGUYEN H.V.-M., LEE B.-M. Influence of upstream land use on dissolved organic matter and trihalomethane formation potential in watersheds for two different seasons. Environ. Sci. Pollut. R. 1, 2014.

5. WILLIAMS C.J., YAMASHITA Y., WILSON H.F., JAFF R., XENOPOULOS M.A. Unraveling the role of land use and microbial activity in shaping dissolved organic matter characteristics in stream ecosystems. Limnol. Oceanogr. 55 (3), 1159, 2010.

6. GRAEBER D., GELBRECHT J., PUSCH M.T., ANLANGER C., VON SCHILLER D. Agriculture has changed the amount and composition of dissolved organic matter in Central European headwater streams. Sci Total Environ. 438, 435, 2012.

7. STEDMON C.A., MARKAGER S. Resolving the variability in dissolved organic matter fluorescence in a temperate estuary and its catchment using PARAFAC analysis. Limnol. Oceanogr. 50 (2), 686, 2005.

8. YANG L.Y., HONG H.S., GUO W.D., HUANG J.L., LI Q.S., YU X.X. Effects of changing land use on dissolved organic matter in a subtropical river watershed, southeast China. Reg Environ Change. 12 (1), 145, 2012.

9. GU L., WU C., WANG X. Land utilization pattern changing and driving force analysis based on remote sensing data in Lin'an. Journal of Zhejiang Forestry College. 26 (6), 870, 2009 [In Chinese].

10. DONG H., QIANG Z., LI T., YIN C., JIN H., XU J. Analysis of the spatial-temporal variation of water quality in Jinxi River, a tributary of Southern Tiaoxi River. Chinese Journal of Environmental Engineering. 3, 772, 2012 [In Chinese].

11. LI Y.F., JIANG P.K., CHANG S.X., WU J.S., LIN L. Organic mulch and fertilization affect soil carbon pools and forms under intensively managed bamboo (Phyllostachys praecox) forests in southeast China. J Soil Sediment. 10 (4), 739, 2010.

12. ZHOU G.M., ZHUANG S.Y., JIANG P.K., XU Q.F., QIN H., WONG M.H., CAO Z.H. Soil Organic Carbon Accumulation in Intensively Managed Phyllostachys praecox Stands. Bot Rev. 77 (3), 296. 2011.

13. JIANG P., XU Q., XU Z., CAO Z. Seasonal changes in soil labile organic carbon pools within a Phyllostachys praecox stand under high rate fertilization and winter mulch in subtropical China. For. Ecol. Manage. 236 (1), 30, 2006.

14. GAO C. Influences of watershed land use on C, N, P export in 
Tiaoxi streams, Zhejiang Province, China. Chines Academy of Forestry. 2013 [In Chinese].

15. MCKNIGHT D.M., BOYER E.W., WESTERHOFF P.K., DORAN P.T., KULBE T., ANDERSEN D.T. Spectrofluorometric characterization of dissolved organic matter for indication of precursor organic material and aromaticity. Limnol. Oceanogr. 46 (1), 38, 2001.

16. MURPHY K.R., BUTLER K.D., SPENCER R.G.M., STEDMON C.A., BOEHME J.R., AIKEN G.R. Measurement of Dissolved Organic Matter Fluorescence in Aquatic Environments: An Interlaboratory Comparison. Environ. Sci. Technol. 44 (24), 9405, 2010.

17. STEDMON C.A., BRO R. Characterizing dissolved organic matter fluorescence with parallel factor analysis: a tutorial. Limnology and Oceanography-Methods. 6, 572, 2008.

18. SIMEONOV V., STRATIS J.A., SAMARA C., ZACHARIADIS G., VOUTSA D., ANTHEMIDIS A., SOFONIOU M., KOUIMTZIS T. Assessment of the surface water quality in Northern Greece. Water Res. 37 (17), 4119, 2003.

19. INAMDAR S., FINGER N., SINGH S., MITCHELL M., LEVIA D., BAIS H., SCOTT D., MCHALE P. Dissolved organic matter (DOM) concentration and quality in a forested mid-Atlantic watershed, USA. Biogeochemistry. 108 (1-3), 55, 2012.

20. FROST P.C., LARSON J.H., JOHNSTON C.A., YOUNG K.C., MAURICE P.A., LAMBERTI G.A., BRIDGHAM S.D. Landscape predictors of stream dissolved organic matter concentration and physicochemistry in a Lake Superior river watershed. Aquat Sci. 68 (1), 40, 2006.

21. WILSON H.F., XENOPOULOS M.A. Ecosystem and seasonal control of stream dissolved organic carbon along a gradient of land use. Ecosystems. 11 (4), 555, 2008.

22. DONG H.Y., QIANG Z.M., WANG W.D., JIN H. Evaluation of rural wastewater treatment processes in a county of eastern China. J Environ Monit. 14 (7), 1906, 2012.
23. HAALAND S., AUSTNES K., KASTE Ø., MULDER J., RIISE G., VESTGARDEN L.S., STUANES A.O. Manipulation of precipitation in small headwater catchments at Storgama, Norway: effects on leaching of organic carbon and nitrogen species. Ambio. 37 (1), 48, 2008.

24. DONG Q.Q., LI P.H., HUANG Q.H., ABDELHAFEZ A.A., CHEN L. Occurrence, polarity and bioavailability of dissolved organic matter in the Huangpu River, China. J Environ Sci-China. 26 (9), 1843, 2014.

25. COBLE P.G. Characterization of marine and terrestrial DOM in seawater using excitation-emission matrix spectroscopy. Mar. Chem. 51 (4), 325, 1996.

26. MURPHY K.R., STEDMON C.A., WAITE T.D., RUIZ G.M. Distinguishing between terrestrial and autochthonous organic matter sources in marine environments using fluorescence spectroscopy. Mar. Chem. 108 (1), 40, 2008.

27. FELLMAN J.B., HOOD E., D'AMORE D.V., EDWARDS R.T., WHITE D. Seasonal changes in the chemical quality and biodegradability of dissolved organic matter exported from soils to streams in coastal temperate rainforest watersheds. Biogeochemistry. 95 (2-3), 277, 2009.

28. MENG F., HUANG G., YANG X., LI Z., LI J., CAO J., WANG Z., SUN L. Identifying the sources and fate of anthropogenically impacted dissolved organic matter (DOM) in urbanized rivers. Water Res. 47 (14), 5027, 2013.

29. BAKER A. Fluorescence properties of some farm wastes: implications for water quality monitoring. Water Res. 36 (1), 189, 2002

30. ZHANG Y.L., ZHANG E.L., YIN Y., VAN DIJK M.A., FENG L.Q., SHI Z.Q., LIU M.L., QIN B.Q. Characteristics and sources of chromophoric dissolved organic matter in lakes of the Yungui Plateau, China, differing in trophic state and altitude. Limnol. Oceanogr. 55 (6), 2645, 2010.

31. ROCHELLE-NEWALL E., FISHER T. Production of chromophoric dissolved organic matter fluorescence in marine and estuarine environments: an investigation into the role of phytoplankton. Mar. Chem. 77 (1), 7, 2002. 